\title{
Micah 2:9 and the traumatic effects of depriving children of their parents
}

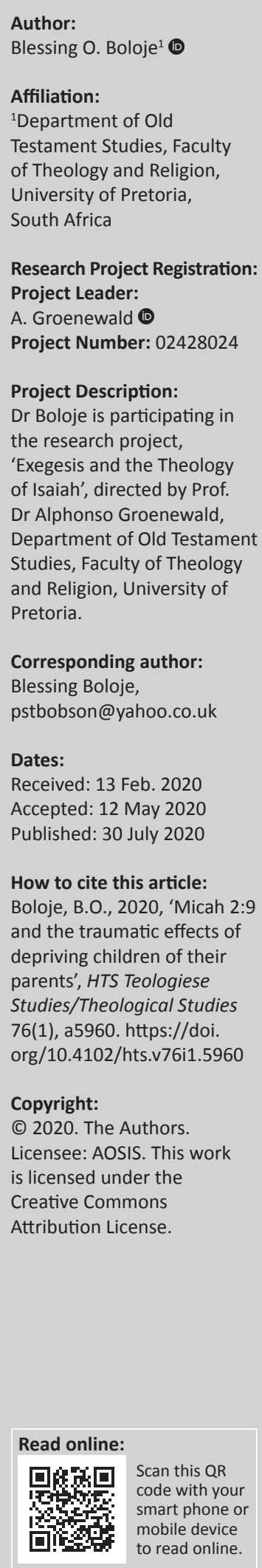

The Hebrew Bible and/or the Old Testament is replete with narratives of families that are devastated and separated by the unfaithfulness of injustice. Such situations are mostly seen to be theologically reprehensible and morally unacceptable. In the book of Micah, the fluidity of the rhetorical characterisation of those who opposed moral values and the godly voice is manifested in shameful actions against women and children. Since children who are deprived of parents are victims, this article attempts to examine Micah 2:9 and the effects of depriving children of their parents against the background of Israel's social ethics of the marginalised minority. As a background, the article begins with a description of the family as an attractive and viable setting for the growth and development of children, continues with a relative examination of data on Israel's social justice and marginalised minority, situates and analyses Micah 2:9 within its context, and then concludes with some effects of depriving children of their parents from the perspective of trauma research.

Contribution: This article brings together insight from trauma research into dialogue with biblical, literary, exegetical and theological discourse. Such creative dialogue generates insightful alternative and viable components of the process of creating a healthy, viable community, and consequently invites readers to the urgent ethical concern for compassion and care for the most vulnerable in society.

Keywords: Micah 2:9; children; traumatic experience; family and societal stability; social justice; marginalised minority.

\section{Introduction}

Undoubtedly, the functionality and viability of a society depends on adherence to and maintenance of acceptable standards or ethical principles such as truthfulness, integrity, equity and justice, respect for human dignity, responsibility and accountability. The violation of these core moral values usually results in instability and disruption of society rather than stability and tranquillity. In the book of Micah, the prophetic accusation exhibits typical characteristics of Ancient Israel and Judah's theocratic society and religious dearness, which was well established in historical and social realities (Allen 1973:32). The literary text of Micah is filled with oracles that indicate how the less privileged and marginalised became victims of oppression (cf. Mi 2:1-11), how traditional moral and social solidarity resulting from Israel's covenant with Yahweh were steadily being disregarded or overlooked, and how the authorised religion of the Jerusalem temple appeared lackadaisical in challenging the deliberate and flagrant scope of infidelity of injustice (Alfaro 1989:6). Micah found his prophetic call in Yahweh's transcendence and in the cry of oppression from the poor and marginalised. Applying the ethical principles of Yahweh's sovereignty, justice and human responsibility, Micah rose to the challenge and categorically condemned religious activities and distorted theological discussion in the face of massive injustice. The fluidity of the rhetorical characterisation of those who opposed moral values and the godly voice is manifested in shameful actions against women and children (Mi 2:9).

The task of this article is that of using the text of Micah 2:9 as a useful and valid window of dialogue on social ethics of the marginalised minority (poor, homeless aliens, widows and orphans), against the background of the traditional honour-and-shame society within which and for which the text was written (cf. Ben Zvi 2000:59). In view of the essential place of the family in moral discourse, and the progressive complexity of social relationships, especially in the field of psychology, this article will, by using Micah's locus of dialogue, examine the effects of depriving children of their parents from the perspective of trauma research.

The purpose is to situate as well as provide contemporary readers with ethical concerns within the larger domain of biblical theology and anthropology. Consequently, Micah's 
rhetorical concerns are indispensable for contemporary ethical reflection.

\section{The family as an attractive setting for a child's development and nurture}

The family, in all of its numerous forms and structures, is essentially a viable and attractive social institution in and around which most of societal development takes place (Dutcher-Walls 2009:1-2). Dearman (1998) remarks that:

'Household' or 'family' in scripture reflects a richness of meaning ... Without raising its importance to an idolatrous level yet affirming its foundational significance for community, the Old Testament presents the family as a metaphor for God's relationship with Israel and a vehicle of grace for human beings. (p. 117)

\section{Anderson (2004) provides a definition of the family as:}

\begin{abstract}
... a group of kin-related people (including fictive kin) who may or may not reside together and whose primary function is to reproduce its members biologically. A household is a person or a group of people who live together in one or more structures, who carry out daily activities necessary for the maintenance and social reproduction of the group within a specific space associated with the residence, and who interact with other households. (p. 111)
\end{abstract}

This definition is vitally related to the description of the home as the indispensable bedrock of human and societal development, as confirmed by Wells (1987):

The home was (and is) the center of human development. The family serves to regulate sexual activity ... sexual drive demands careful regulation, else a society is thrown into indiscriminate sexual activity, high incidences of illegitimate birth, and dehumanisation of women as sexual objects. Every culture recognises the need to sanction the sexual life of its members and assure responsible parents for its children. The family serves as the agency of reproduction ... Families are thus crucial to the very survival of the race. The family socialises the members of a culture. The family transmits to its children, the goals, values, norms, obligations, expectations, rules, rights, and so on, which characterise life in a given society ... Ideally, husband, wife and children all find their love needs met in the family circle. The family gives the members of society their identity. Religious, social, ethnic, and national identity is conferred, first of all, in and by the family. (pp. 51-52)

Certainly, reflection on the family cannot be viewed as a unitary or simple social institution, but as a comprehensively indispensable bedrock for the development of various capacity for intimacy and devotion, not only with God and other human beings, but also primarily as the setting where both spiritual and moral values are extended across generations. Studies on 'the family in the Bible' (cf. Sanders 2002:117-128) and Life in Biblical Israel (King \& Stager 2001) examine various aspects of the usefulness of the family. King and Stager (2001) clearly negotiated on the essential and conceptual correlation of the Israelite societal structure of the family when they said:
The family and household provide the central symbol about which the ancient Israelites created their cosmion, the world in which members of that society expressed their relationships to each other, to their leaders ... and to the deity. (p. 5)

The research of De Vaux (1961:8) on Ancient Israel: Its Life and Institutions, written from the perspective of Israel's social life, describes 'the father's house' (אַב בֵית) as consisting of 'the father, his wife or wives and their unmarried children but also their married sons with their wives and children, and the servants' (Dearman 1998:117). The description of the family as אַב בֵית obviously reflected the principal kinship unit in ancient Israel, of a male-headed, multigenerational household. The household was formed 'by endogamous marriage rites, patrilineal succession, and inheritance customs that privileged the eldest son ...' (Dearman 1998:117). This family size description is made clearer in the book of Micah, where the exemplary size of a family unit that realises all the possible relationships has five significant members: a father-husband who is the head of the family, directly related to his wife (7:5) and his son (7:6); a wife-mother, the wife of the head of the family and so related to her husband (7:5) and in charge of the women of the subsequent generation (daughter and daughterin-law, 7:6); a son (7:6); a daughter (responsible to her mother, $7: 6)$, and a son's wife $(7: 6)$ who is related more directly to her mother-in-law (Andersen \& Freedman 2000:569).

Within the context of the ancient Israelite society, the family is described corporately not only in terms of its human members but also in relation to possessions, which allowed it to function in society. Although the literary contents of the Hebrew Bible and/or the Old Testament originated from only segments of ancient Israel (Dearman 1998:117), the description of the family in ancient Israelite society included a socio-economic profile that enabled families and/or households to be viewed as 'the nexus of social reproduction and production in the forms of practice' (Brandon \& Barile 2004:8). An illustration of the socio-economic assumption of the family in ancient Israel is found in the prohibition of the tenth commandment: 'You shall not covet your neighbor's house' [רעֶֶ] [בית (Ex 20:17 New American Standard Bible [NASB]). Dearman (1998) notes:

As the prohibition makes clear, the neighbor's 'house' can be defined by things the neighbor possessed as part of his household (e.g., wife, servant, and domestic animals). The deuteronomic version simply refers to that which belongs to the neighbor without specific reference to the house (Deut 5:21). In its brief enumeration of things forbidden to covet, there is a reference to the neighbor's land, an important element in the profile of families and clans. (p. 118)

These socio-economic profiles granted many ancient societies an essential medium of describing 'their corporate identity and many of their political and social relations' (Dearman 1998:118). Consequently, for ancient Israel, the very existence, identity, security and happiness of which found expression above all in such intimate relationships within the community, the crisis that affects a family is undeniably a socio-culturally defining moment for sustainable family living. In fact, the harmony and stability 
of the basic family structure was of such significant and critical value to the Israelite (cf. Ex 20:12; 21:15, 17; Deut 21:18f.; Lev 20:9) (Mays 1976:152) that its disintegration through situations of injustice and polarisation was indeed a portrayal of agony and torment.

\section{Social justice and marginalised minority}

In the Hebrew Bible and/or the Old Testament, one finds glimpses of data on justice in both the history and literature (Wright 2006:253) that are differently approached depending on the perspective (Marshall 2012:12).

Textual data on justice, such as those of Job 29:16, Isaiah 58:6 and Jeremiah 21:12, indicate that justice is not just a principle of evaluation but a call for a practical and redemptive action (Mott 1993:79). The concern for justice embraces all necessary structures and legitimate means of appropriating available opportunities, privileges, and other entitlements for the benefit of deserving individuals or groups within a community, so as to enhance and sustain the well-being of people, in particular, and the community to which they belong, in general. In this case, the just person is characteristically seen as one who is passionately attentive to the plight of the vulnerable and needy (Brueggemann 2002:177). Clearly, in the Hebrew Bible and/or the Old Testament, it is difficult for one to doubt the existence and reality of the plight of the oppressed and marginalised minority, who are predisposed to economic exploitation, social isolation, oppression, and poverty. The category of the poor and marginalised identified in the Hebrew Bible and/or the Old Testament includes (Noell 2017):

... those living at society's margin as widows, orphans, or strangers (ebyon), those personally negligent (atsel), and those economically oppressed (ani) ... The atsel is consistently identified in the book of Proverbs as the negligent one who is not to be given provisions from the community. (p. 186)

Specifically, the foreigner, fatherless and widow are regarded as Yahweh's objects of special concern (Lv 19:33-34; Job 22:9; $\operatorname{Pr} 15: 25)$. This concern is premised on the fact that each of these has lost the protection of close family members, and so is susceptible to exploitation. The concern finds clear expression within the social regulation of the Mosaic Law (Ex 22:22; Dt 10:18; 14:29; 24:17-21; 26:13; 27:19), and is severally repeated in prophetic messages (Is 1:17; 10:2; Jr 7:6; 22:3; 49:11; Ez 22:7) (Mcllroy 2011:184).

Consequently, the concern for justice is not in any way immaterial. In fact, it is grounded in the urgent need to relieve and emancipate the victims of oppression. Perhaps one of the most solemn ethical concerns of the Hebrew Bible and/or the Old Testament is that of the protection and prevention of abuse of the poor, the marginalised, and the socially disadvantaged (Ps 72:2-4, 12-14; Jr 22:15-16), through just civil rule and economic policies. This was a unique moral leadership prize worth seeking by Israel's leadership within the ancient world (Wright 2006:313; cf. Gay 2014:620-636).

The idea of justice and its interrelated concepts equipped Israel's prophetic exhortation and inspiring communication as they acted as arbitrators between Israel's God, kings and covenant people (cf. Carroll 2006:169-176, 2012:185-193; Friedman 2011:297-305). In the book of Micah, attention is drawn to socio-economic ethics of human values and deep social solidarity and concern for the poor and marginalised. Although Micah condemned the general sin of covenant unfaithfulness and idolatry (1:5-7), the perversion of justice in the interest of materialism by those in leadership positions, whether administrative $(3: 1,9,11,7: 3)$ or religious $(3: 5,11)$, the specific transgression of how the wealthy had abused their position through shameful actions of marginalisation, and consequently the traumatising of children (2:9), is the focus of the next section of this article.

\section{Micah 2:9 and victims of marginalisation}

NASB The women of my people you evict each one from her pleasant houses. From their children you take away my splendor forever.

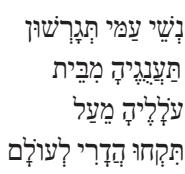

Micah 2:9 falls within a literary unit that deals with social ethics, divine character and patronship, distorted theological positions, and judgement (2:6-11) (Ben Zvi 2000:56). The unit presents its readers and/or intended readers with the challenge of coping with the density of changes in speaker or speakers, grammatical inconsistencies, and the presence of some uncommon forms (Ben Zvi 2000:56). The content of the speeches indicates that it is clearly a disputation or dialogue that sketched out the perspective of Micah's opponents, that of distorted theological justification of crimes (2:6-7); and the prophet's perspective and counter argument, that of condemnation of injustice (2:8-11) (Dempster 2017:80; Sweeney 2000:357). The fluidity in the characterisation of the misdeeds of those who neglect or oppose the godly voice, using the language of oppression and imagery of dispossession, is shared by the accusation in 2:1-2 (Mignon 2001:83; cf. Dempster 2017:80; Sweeney 2000:357). The increased degree of charges of shameful crimes against the weak and marginalised is strongly suggested by the transition from the image of economic piracy and dispossessing male owners (2:1-5) to that of continuity of similar actions against women and children (2:9).

Radically, within this unit, there is the heightening of the negative characterisation of the powerful enemies of the people, which does not end with their description as thieves without any integrity as they undermine Yahweh's honour as the patron of women and children of his people (2:9), but with the mockery of their theological wisdom (cf. 2:7, 11) (Ben Zvi 2000:59-60).

The precise historical setting of the reading and re-reading for which the unit of 2:6-11 is written as well as the setting of the speech of the speaker is similar to the setting of the previous unit (2:1-5) (Ben Zvi 2000:62-63; Jenson 2008:119). The implied author of the text does not suggest that the intended readers 
approach the text from a perspective informed by a particular historical narrative or metanarrative. However, the link with occupation and control of fields and houses allows for an interpretation of the setting somewhere in the larger scope of time indicated in the superscription - an 8th century context (1:1) (Andersen \& Freedman 2000:17-20; Ben Zvi 2000:63; Coomber 2011:396-432; Kaiser 1998:352; McKeating 1971:162; Walton, Matthews \& Chavalas 2000:780-781).

Judged by the grammatical structure of the preceding verse (2:8), Micah's opponents are not morally upright, 'they are "the enemy of my people", and have accumulated a record of successful oppression that would justify the wrath of God many times over' (Mays 1976:71). He describes the victims of

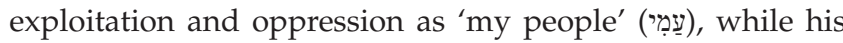
opponents play the role of the enemy (אוֹיב). Here, Micah attempts to create a distinction in the general population of Judah, disconnecting the vulnerable from their oppressors, and leaving out the latter from the group of which he is a part. In expanding the image of the powerful oppressors as the enemy, who, in their passionate drive for materialism, Micah describes as claiming the cloak of those who make efforts to live in peace, working for their bread and endeavouring to keep together the bonds of their community; these enemies are not only greedy and ruthless marauders who despoil their helpless victims and captives (2:8), but also those who undermine Yahweh's honour as the patron of women and children of his people. The crimes of verse 9 cut to the heart of Israel's social ethics (cf. Ex 22:21-22; Dt 24:1718). The crimes that are listed in these verses (8-9) are not the immediate actions of a foreign attacker, but obviously, violations of the covenant within the community of Judah. The specific details indicate some particular occasion, very recent (according to verse 8), provisionally identified with the devastating strife in Israel in the reign of Ahaz (Andersen \& Freedman 2000:321)

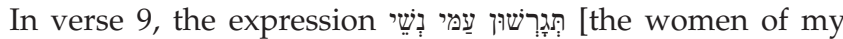
people you evict/cast out/expelled] is a reference to the Israelites' women, not strangers, widows of the debt-ridden husbands, whose husbands had probably been slain with the sword of war, or unjustly condemned to death so as to forfeit their estates. By the special provision of God's law (Ex 22:21$22)$, these women are supposed to be tenderly and mercifully cared for.

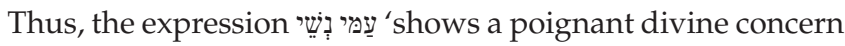
for the women who are robbed of the place where they

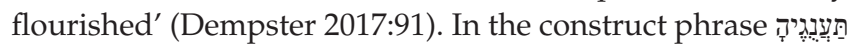
מִָּּית [from her house of delight, or from her pleasant house],

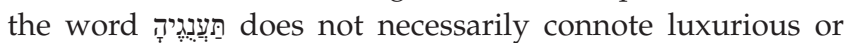
comfortable homes, but the value of the house for the occupant (Andersen \& Freedman 2000:321). If the husbands of these women had died, no doubt their houses would be essentially symbols and sources of joy, delight, comfort and security. These were houses where they had had their husbands and children, and now, they are disconnected from their beloved habitation, and domestic conveniences.
The parallelism with עלָלֶיָ [their young children] suggests that the women here are not necessarily widows, even though they would be particularly vulnerable and protected by covenant law. According to Andersen and Freedman (2000:321-322),

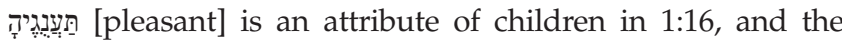
repetition of this rare word in 1:16 and 2:9 (and elsewhere in $\mathrm{Pr}$ 19:10; Ec 2:8; Song 7:7) indicates a connection of the theme in Micah 1 and 2. In 1:16, the bereaved mother is addressed in the singular and could be taken as metaphorical for each of the listed cities, but especially for Jerusalem, as the mother of

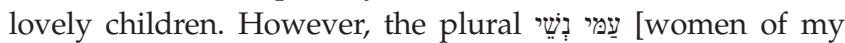
people] in 2:9 provides the balance in favour of human mothers (Andersen \& Freedman 2000:321-322). In 1:16, only one atrocity is involved - the expulsion of children (not women or mothers), but in 2:9, the atrocity involves separation of mothers

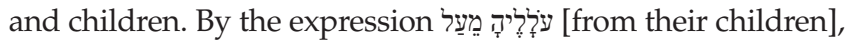
Micah underscores that separating children from their homes is tantamount to removing them from their potential to be Yahweh's image bearers, flourishing in the land that Yahweh has graciously given to his people as a glorious inheritance.

The most flagrant violation that is highlighted by Micah is that of depriving the children of Yahweh's glory forever (תִקֶת

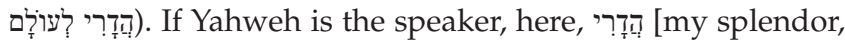
glory] seems to be the object of תְִָּז [you took away]. Although דָדָר [splendor, glory] refers to God's splendor, especially in a cultic context, the symmetrical correspondence

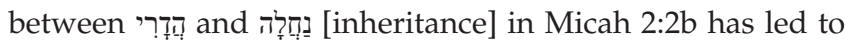
the interpretation of the appellation הִדְר [my splendor, glory] to imply all exclusively divine and/or glorious privileges which these children are expected to enjoy as Yahweh's people and his special care (Allen 1976:293). By means of injustice, violence and oppression, these enemies have ruined the posterity of the children by driving them out of their houses and separating them from their parents. The enemies have either carried out these contemptible acts continually or they intend to stand by what they have done forever (לְ̣). A sequential and composite reading of these crimes will indicate a portrait of the typical family, where fathers have been robbed of and disconnected from their families (possibly by slavery or forced labour), followed by the eviction of their wives, and finally their children have been disinherited (Jenson 2008:126). Micah's rebuttal of their claim to uprightness is thus aptly sketched out in violation of social ethics, shameful robbery, and oppression of the powerless.

\section{Micah 2:9 and traumatised children}

Critical issues of social disorders such as violence, political instability, economic unrest, exploitation, injustice and oppression create traumatic experiences for people and society at different levels (Kavusa 2016:481-482). In the field of trauma research, trauma is described as 'suffering that remains' (Groenewald 2018:89).

Trauma is a situation in which the victim is incapacitated by forces that overwhelm the familiar routines of daily existence (Frechette 2015:23). According to Smith-Christopher (2002:79), a situation is traumatic 'when events exceed the ability of the 
group to cope, to redefine and reconstruct their world.' In his descriptive analysis of the core aspect of a traumatic experience which deals especially with the problem of integration, Groenewald (2018) notes:

The overwhelming nature of traumatic experiences hinders the human processes of adaptation, and the force of the violence causes an inability to both integrate and incorporate this experience into a new framework of meaning. The challenge in the aftermath of this traumatic experience is to again orientate oneself to life, befriend the world, and restore trust and connections. (p. 89)

The literary component of the discussion of trauma that is found in various literature obviously addresses people of different cultural backgrounds and across fields of study, including biblical studies and Christian theology (Caruth 2016:116-117). In the field of humanities and social science, studies indicate that the parent-child relationship is essential to a child's sense of self awareness, trust and safety. However, when children experience the separation or loss of parents and/or caregivers, either permanently as a result of death, or for unpredictable periods of time as a result of other social circumstances, such children may develop post-traumatic experiences on account of separation from their primary caregivers. Scientific research on the separation of children from parents generally reveals the devastating effects both for child and parent. Wan's (2018) cross-cultural research provides insight into the physical and psychological impact of child-parent separation in a wide range of circumstances. According to Wan (June 2018:18), 'the effect is catastrophic'. Goydarzi (June 2018:20), in her 2018 article, 'Separating Families May Cause Lifelong Health Damage', remarks that '... family separation may also lead to long-term chronic medical conditions like cardiovascular disease, hypertension, obesity, and decreased longevity.' Other traumatic effects of separation include higher levels of child negativity toward parents (especially mothers), aggression, reduced selfcontrol, poor resilience, increased risks of depression, difficulty with social functioning, attachment issues, and post-traumatic stress disorder. The child 'lacks the cognitive abilities to understand the continuity of maternal availability' (Howard et al. 2011:5-26).

Micah underscores that children who are deprived of parents are victims. Here, the traumatic effects of separation of children from parents in Micah's locus of reflection are briefly synthesised. Children who are deprived of parents or experience separation from parents in life are faced with the traumatic experience of instability and chaos, especially unanticipated interruption of conventional family routines. As demonstrated by Micah in his charges, the implications of depriving children of their parents do not only alter the composition of the family by jeopardising the predictability of the environment of the children, but such perversion of moral value is seen as a pointer to family insecurity. According to Micah, these fatherless (or parentless) children are ruthlessly stripped of their privileged blessings of parental nurture and religious upbringing, which are crucial components of the developmental outcomes of children. Interestingly, the Hebrew and/or the Old Testament provides the environmental context for both the spiritual and moral nurture of children (cf. Dt 6:4-7; Pr 22:6; 23:13-14; 29:17). Such context does not emanate only from a viable relationship with God and walking under the control of God but is also a product of the tender and affectionate care of God-fearing parents.

God's charge to parents to ' $[t]$ rain up a child in the way he should go, even when he is old he will not depart from it' (Pr 22:6, NASB) requires parents' sensitive and responsive dedication to raising children in the admonition and nurture of the Lord, with positive child outcomes in several domains: affection (in a basic family context), dedication (of both parent and child), instruction (in essential content), discipline (both in words and actions), and paradigm (the parents' lived reality) (cf. Cavanagh \& Huston 2006:551-581; Guzzo \& Lee 2008:44-61; Taylor 2005:61-78). Parents deal seriously with attitudes of children in their home as well as with their actions. The way they deal with their children, in a great measure, will determine how the children will respond to God's dealing with them (Lessin 1978:81). The extent of their diligent dedication in this respect will be confirmed later in the tide and course of the family and the nation's stability and security.

Certainly, in Micah's rhetoric of moral perversion of the enemies of the people, the essential environmental ingredients in training children in order to give them a vital perception of the reality of God by parental presence, exemplary lifestyle or model are completely jeopardised. Consequently, children are vulnerable and may not be expected to grasp the reality of God and relate well with Him.

Another important highlight from Micah's rhetoric of the moral perversion, which constitutes trauma for children deprived of their parents, is the deprivation of both civil and religious liberties, their paternal estates and inheritances, and the enjoyment of their own land. The close relationship of ancient Israel and the ancient Near East social civilisation (cf. Frymer-Kensky 1981:209-214; TaggarCohen 1998:74-94) allows for a clear articulation of family inheritance tradition and law, to express the institutional basis of ancient Israelite society. It is clear, for example, how in the book of Numbers 'the construction of the society is strongly tied to the prospect of the inheritance of the land of Canaan, familial law seems to be a natural way of presenting legal actions' (Taggar-Cohen 1998:93).

The structure of the family, as such an essential social institution in ancient Israel, provided the opportunity for children to be grounded in both civil and religious rights: family law, marriage choice, divorce, heirship, inheritance and redemption (Steinberg 1993:137). Biblical law and tradition made provision for the transfer of real property houses, lands and fields (cf. Gn 48:21-22; Lv 25:11-34; 27:16-25). While parents are required to nurture their children concerning God's expectation (Dt 6:6-7), most importantly, parents have the responsibility of making sure that their children are well informed of their inheritance, so as to maintain the status and survival of the family. 
Certainly, inheritance was a privilege gift, and support given by a parent to his son (cf. Dt 21:15-17). At the demise of their fathers, it seems that in early history, sons traditionally and legitimately inherited the property of their fathers:

Sons, if any, normally were implied to be the sole heirs (absent a surviving widow) in numerous other biblical texts, e.g., Judges 11:1-2; 2 Chronicles 21:1-3; Proverbs 17:2; and Luke 12:13.

(Hiers 1993:124-125)

From the narrative of Genesis, it is clearly indicated that Abraham gives 'all that he has to Isaac' (Gn 24:36; 25:5-6). While family inheritance law and tradition express the foundation and structure of Israelite society, the rhetorical description of Micah is such that it shattered the family peacefulness and social solidarity. In Micah 2:9, the powerful, in their desperate drive for property, left the vulnerable children with no security; they were deprived of the comfort and pleasure of life, property and/or liberty without consideration. They lost the dignity and honour of parental nurture, of property and home, and of recognition in a community of their own (Mays 1976:71). For children to realise that they have been deprived of parents who will nurture and train them to abide by lived example and deliberate choice, are uninformed concerning laws that will equip them to take responsibility for their future, and have been dispossessed of material possessions (land, house, wealth) is to thrust them into a traumatic realm and experience. The intensity of Micah's accusation and the anguish he experienced is apparent in the language with which he rehearsed the crimes of the enemies of his people

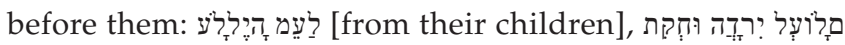
[you have taken Yahweh's glory forever]. The children, whose existence is destroyed by the greed and exploitation of the powerful, are being forced to grow up in want and ignorance, or be sold into slavery. Consequently, rather than living with a deep sense of dignity and selfworth, they now live with feelings of contempt that are destructive to both themselves and society. For such children, there is no future but poverty, slavery and servitude (Mays 1976:71).

\section{Conclusion}

Children are a fundamental part of a family and societal stability. It is, however, a horrific irony to imagine a permanent separation of children from their parents. Whatever the situation is that may have led to such separation, the agony of wrestling with the reality of separation invites theological and ethical reflection. Since the family constitutes a fundamental setting for human development and nurture, the traumatic effects of separating children from or depriving them of their parents, which could be devastating and lifelong, are of supreme theological and ethical concern. Truly, the tears and suffering of those whose rights are being violated (imagine seeing children weeping, and parents bereft of their children) speaks. When people are marginalised or taken advantage of in society, the value of their lives is truly diminished and society disintegrates. Micah's rhetoric of children deprived of parents invites readers to display urgent ethical concern for compassion and care for those suffering, especially the most vulnerable in society. Additionally, the narrative invites readers to develop structures that will strengthen family life, advance the welfare of children, help to protect children from abuses, and increase their distance from the situation of socio-economic and political power that will undermine their stability.

\section{Acknowledgements Competing interests}

I declare that I have no financial or personal relationships that may have inappropriately influenced me in writing this article.

\section{Author's contributions}

I declare that I am the sole author of this research article.

\section{Ethical consideration}

I confirm that this article followed all necessary ethical standards for a research without direct contact with human or animal subjects.

\section{Funding information}

This research received no specific grant from any funding agency in the public, commercial, or not-forprofit sectors.

\section{Data availability statement}

Data sharing is not applicable to this article as no new data were created or analysed in this study.

\section{Disclaimer}

Essentially, the views expressed in this article are those of the author and not certainly reflect any official policy or position of any of the affiliated institution of the author.

\section{References}

Alfaro, J.I., 1989, Justice and loyalty: A commentary on the book of Micah, William B. Eerdmans Publishing Company, Grand Rapids, MI.

Allen, L.C., 1973, 'Micah's social concern', Vox Evangelica 8, 22-32.

Allen, L.C., 1976, The books of Joel, Obadiah, Jonah and Micah, The New International Commentary on the Old Testament, Wm. B. Eerdmans Publishing Co., Grand Rapids, MI.

Andersen, F.I. \& Freedman, D.N., 2000, Micah: A new translation with introduction and commentary, AB 24E, Doubleday, New York, NY.

Anderson, N., 2004, 'Finding the space between spatial boundaries and socia dynamics: The archaeology of nested households', in K.S. Barile \& J.C. Brandon (eds.), Household chores and household choices: Theorizing the domestic sphere in historical archaeology, pp. 109-120, University of Alabama Press, sphere in historica

Ben Zvi, E., 2000, Micah, Forms of the Old Testament Literature 21B, Eerdmans, Grand Rapids, MI.

Brandon, J.C. \& Barile, K.S. 2004 'Introduction: Household chores; or, the chore of defining the household', in K.S. Barile \& J.C. Brandon (eds.), Household chores and household choices: Theorizing the domestic sphere in historical archaeology, pp. 1-14, University of Alabama Press, Tuscaloosa, AL. 
Brueggemann, W., 2002, Reverberations of faith: A theological handbook of Old Testament themes, Westminster John Knox Press, Louisville, KY.

Carroll, R.D., 2006, 'A passion for justice and the conflicted self: Lessons from the book of Micah', Journal of Psychology and Christianity 25(2), 169-176.

Carroll, R.D., 2012, 'Ethics', in M.J. Boda \& J.G. McConville (eds.), Dictionary of the Old Testament prophets, pp. 185-193, Inter-Varsity Press, Downers Grove, IL.

Caruth, C., 2016, Unclaimed experience: Trauma, narrative, and history, 20th anniversary edn., Johns Hopkins University Press, Baltimore, MD.

Cavanagh, S.E., \& Huston, A.C., 2006, 'Family instability and children's early problem behavior', Social Forces 85, 551-581. https://doi.org/10.1353/sof.2006.0120

Coomber, M.J.M., 2011, 'Caught in the crossfire? Economic injustice and prophetic motivation in eighth-century Judah', Biblical Interpretation 19, 396-432. https:// doi.org/10.1163/156851511X595576

De Vaux, R., 1961, Ancient Israel: Its life and institutions, transl. J. McHugh, McGrawHill, New York, NY.

Dearman, J.A., 1998, 'The family in the Old Testament', Interpretation: A Journal of Bible and Theology 52(2), 117-129. https://doi.org/10.1177/002096430005200202

Dempster, S.G., 2017, Micah, The Two Horizons Old Testament Commentary, William B. Eerdmans Publishing Company, Grand Rapids, MI.

Dutcher-Walls, P., 2009, 'The clarity of double vision: Seeing the family in sociological and archaeological perspective', in P. Dutcher-Walls (ed.), The family in life and in and archaeological perspective, in P. Dutcher-Walls (ed.), The family in life and in pp. 1-15, Library Of Hebrew Bible/Old Testament Studies 504, T \& T Clark pp. 1-15, Library Of Hebrew
International, New York, NY.

Frechette, C.G., 2015, 'The Old Testament as controlled substance: How insights from trauma studies reveal healing capacities in potentially harmful Texts', Interpretation 69, 20-34. https://doi.org/10.1177/0020964314552624

Friedman, H.H., 2011, 'Messages from the ancient prophets: Lessons for today' International Journal of Humanities and Social Science 1(20), 297-305.

Frymer-Kensky, T., 1981, 'Patriarchal family relationships and near eastern law', Biblical Archaeology 44, 209-214. https://doi.org/10.2307/3209666

Gay, C.M., 2014, 'Poverty', in P. Oslington (ed.), The Oxford handbook of Christianity and economics, pp. 620-636, Oxford University Press, Oxford.

Goydarzi, S., 2018, June, 'Separating families may cause lifelong health damage', Scientific American, viewed 17 October 2019, from https://www.scientificamerican. scientific American, viewed 17 October 2019, from https://www.scientictic
com/article/separating-families-may-cause-lifelong-health-damage/.

Groenewald, A., 2018, "'Trauma is suffering that remains." The contribution of trauma studies to prophetic studies', Acta Theologica Supplement 26, 88-102. https://doi. org/10.18820/23099089/actat.Sup26.5

Guzzo, K.B. \& Lee, H., 2008, 'Couple relationship status and patterns in early parenting practices', Journal of Marriage and Family 70, 44-61. https://doi. org/10.1111/j.1741-3737.2007.00460.x

Hiers, R.H., 1993, 'Transfer of property by inheritance and bequest in biblical law and tradition', Journal of Law \& Religion 10, 121-155, viewed 17 October 2019, from http://scholarship.law.ufl.edu/facultypub/737.

Howard, K., Martin, A., Berlin, L.J. \& Brooks-Gunn, J., 2011, 'Early mother-child separation, parenting, and child well-being in early head start families' Attachment \& Human Development 13(1), 5-26. https://doi.org/10.1080/146167 34.2010 .488119

Jenson, P.P., 2008, Obadiah, Jonah, Micah: A theological commentary, LHBOTS 496 , T \& T Clark, New York, NY.
Kaiser, W.C., Jr., 1998, A history of Israel, Broadman \& Holman, Nashville, TN.

Kavusa, K.J., 2016, 'Social disorder and the trauma of the earth community: Reading Hosea 4:1-3 in light of today's crises', Old Testament Essays 29(3), 481-501. https://doi.org/10.17159/2312-3621/2016/v29n3

King, P.J. \& Stager, L.E., 2001, Life in biblical Israel, Library of Ancient Israel, Westminster John Knox, Louisville, KY.

Lessin, R., 1978, How to be parents of happy and obedient children, Omega Publications, Medford, OR.

Marshall, C., 2012, 'Divine justice as restorative justice', Center for Christian Ethics 11-19, viewed 12 September 2019, from https://www.baylor.edu/content/ services/document.php/163072.pdf.

Mays, J.L., 1976, Micah: A commentary, Old Testament Library series, Westminster Press, Philadelphia, PA.

McKeating, H., 1971, The books of Amos, Hosea, Micah, Cambridge University Press, Cambridge.

Mcllroy, D., 2011, 'The mission of justice', Transformation: An International Journal of Holistic Mission Studies 28(3), 182-194. https://doi.org/10.1177/0265378 811404789

Mignon, J., 2001, The conceptual coherence of the book of Micah, JSOTSup 322, Sheffield Academic Press, Sheffield.

Mott, S.C., 1993, A Christian perspective on political thought, Oxford University Press, Oxford.

Noell, E., 2017, 'Land grabs, unjust exchange, and bribes: Economic opportunism and the rights of the poor in ancient Israel', Southwestern Journal of Theology 59(2), 183-199.

Sanders, J.A., 2002, 'The family in the Bible', Interpretation 32, 117-128. https://doi. org/10.1177/014610790203200302

Smith-Christopher, D.A., 2002, A Biblical theology of exile, Fortress Press, Minneapolis, $\mathrm{MN}$

Steinberg, N., 1993, Kinship and marriage in Genesis: A household economics perspective, Fortress, Minneapolis, MN

Sweeney, M., 2000, The twelve prophets: Micah, Nahum, Habakkuk, Zephaniah, Haggai, Zechariah, Malachi, Liturgical Press, Collegeville, PA.

Taggar-Cohen, A., 1998, 'Law and family in the book of Numbers: The Levites and the Tidennūtu documents from Nuzi', Vetus Testamentum 48, 74-94. https://doi. org/10.1163/1568533982722018

Taylor, R.D., 2005, 'Family and neighborhood environments and the adjustment and achievement of African American adolescents', in R.D. Taylor (ed.), Addressing the achievement gap: Findings and applications, pp. 61-78, Information Age Publishing, Greenwich, CT.

Walton, J.H., Matthews, V.H. \& Chavalas, M.W., 2000, The IVP bible background commentary Old Testament, Inter-Varsity Press, Downers Grove, IL.

Wan, W., 2018, June 18, 'What separation from parents does to children: The effect is catastrophic', Washington Post, viewed 17 October 2019, from https://www. washingtonpost.com/national/health-science/what-separation-from-parents-doesto-children-the-effect-is-catastrophic/2018/06/18/c00c30ec-732c-11e8-805c4b67019fcfe4_story.html.

Wells, R.C., 1987, 'The subtle crises of secularism: Preaching the burden of Israel', Creswell Theological Review 2(1), 39-61.

Wright, C.J.H., 2006, Old Testament ethics for the people of God, Inter-Varsity Press, Leicester. 